\title{
The intricate relationship between intellectual property exhaustion and free movement of goods in regional organizations: comparing the EU/EEA, NAFTA, and ASEAN
}

Irene Calboli

Texas A\&M University School of Law, irene.calboli@gmail.com

Follow this and additional works at: https://scholarship.law.tamu.edu/facscholar

Part of the Intellectual Property Law Commons, and the International Trade Law Commons

\section{Recommended Citation}

Irene Calboli, The intricate relationship between intellectual property exhaustion and free movement of goods in regional organizations: comparing the EU/EEA, NAFTA, and ASEAN, 9 Queen Mary J. Intell. Prop. 22 (2019).

Available at: https://scholarship.law.tamu.edu/facscholar/1302

This Article is brought to you for free and open access by Texas A\&M Law Scholarship. It has been accepted for inclusion in Faculty Scholarship by an authorized administrator of Texas A\&M Law Scholarship. For more information, please contact aretteen@law.tamu.edu. 


\title{
The intricate relationship between intellectual property exhaustion and free movement of goods in regional organizations: comparing the EU/EEA, NAFTA, and ASEAN
}

\author{
Irene Calboli* \\ Professor of Law, Texas A\&M University School of Law
}

This article explores the relationship between national rules on the exhaustion of intellectual property (IP) rights and cross-border trade within regional organizations. In particular, this article compares three distinct approaches adopted by: the European Union (EU); the North American Free Trade Area (NAFTA); and the Association of South East Asian Nations (ASEAN). Based on this comparison, this article concludes that in order to effectively promote the free movement of goods, members of regional organizations need to consistently adopt national policies on IP exhaustion that support, at least, a system of regional exhaustion such as currently found in the EU. However, this article also posits that different regional organizations may decide to adopt a variety of approaches on IP exhaustion. These variations may be based on the different stages of national development of the various members of a regional organization or the size of national markets and economic strategies, including their current level of international trade and whether this trade is primarily with other members of the same organization or with third countries. With time, different national approaches on IP exhaustion may change and lead to a higher level of harmonization to promote a full-scale free movement of goods within a regional organization.

Keywords: intellectual property exhaustion, free movement of goods, regional free trade areas, European Union, NAFTA, ASEAN

\section{INTRODUCTION}

This article explores the relationship between national rules on the exhaustion of intellectual property (IP) rights and cross-border trade within regional organizations. Notably, it describes how IP rights can represent a barrier to the free movement of

\footnotetext{
* Visiting Professor Nanyang Business School, Nanyang Technological University; Fellow, Transatlantic Technology Law Forum, Stanford University; Distinguished Fellow, Royal University of Law and Economics (Cambodia). I would like to thank Damian Chalmers and the participants to the workshop 'Regional Organization and Regional Integration', London School of Economics (December 2016) and the National University of Singapore (August 2017) for useful comments and feedback. I am also thankful to an anonymous reviewer for her excellent suggestions, and to Professor Johanna Gibson for her comments and feedback on an earlier draft.
} 
goods absent consistent national exhaustion rules permitting parallel imports - that is, imports of genuine products by unauthorized third parties unrelated to IP owners. In particular, this article refers to and compares three distinct approaches adopted by different regional organizations in this respect. The European Union (EU) has long prioritized the creation of the EU internal market, and Member States have, as a result, adopted consistent rules on Community-wide exhaustion for all IP rights across the EU to promote intra-EU free movement of goods. The North American Free Trade Area (NAFTA) does not harmonize national exhaustion policies and members adopt somewhat diverging rules; but it was never intended to become an internal market and promote a full-fledged free movement of goods. The Association of South East Asian Nations (ASEAN) also does not regulate national exhaustion policies, but (differently than NAFTA and similarly to the EU) does aim at creating an internal market for goods, an objective that cannot be reached unless ASEAN members harmonize their national exhaustion rules.

Based on this comparison, this article concludes that in order to effectively promote the free movement of goods, members of regional organizations need to consistently adopt national policies on IP exhaustion supporting, at least, a system of regional exhaustion. However, this article also posits that different regional organizations may decide to adopt a variety of approaches on IP exhaustion. These variations may be based on the different stages of national development of the various members of a regional organization or the size of national markets and economic strategies, including their current level of international trade and whether this trade is primarily with other members of the same organization or with third countries. With time, different national approaches on IP exhaustion may change and, as happened in the EU, lead to a higher level of harmonization to promote a full-scale free movement of goods within a regional organization. However, this is not always the case, as not all regional organizations intend to achieve full-scale regional economic integration. Separate national economic and social interests may also continue to prevail over the interest to promote regional free movement of goods. This will likely be the case for the NAFTA Members. Only time will tell if ASEAN will move towards a greater degree of regional economic integration, including promoting parallel imports of IP-protected goods within ASEAN.

\section{INTELLECTUAL PROPERTY, THE PRINCIPLE OF EXHAUSTION, AND FREE MOVEMENT OF GOODS}

The doctrine of IP exhaustion, also known as 'first sale' in the United States (US), is a crucial doctrine in IP theory, as it limits the rights of IP owners to control the distribution of their products after their first lawful release in the market. This doctrine was developed in the nineteenth century to balance the rights of IP owners to prevent the inappropriate use of their IP rights with the rights of retailers, second-hand dealers, and consumers to freely display, advertise, and resell the products that they lawfully purchased in the market, even if those actions directly compete with the IP owners' business activities in the same market. $^{1}$

1. See, eg, Christopher Heath, 'Parallel Imports and International Trade' (1997) 28 I.I.C. 623; Herman Cohen Jehoram, 'International Exhaustion versus Importation Right: A Murky Area of Intellectual Property Law' (1996) 4 G.R.U.R. Int'1 280; John C Hilke, 'Free Trading or FreeRiding: An Examination of the Theories and Available Empirical Evidence on Gray Market Imports' (1988) 31 World Competition L \& Econ. Rev. 75. 
Generally, there have been no major controversies regarding the application of this doctrine within national markets, with the exception of the transfer of digital goods and self-replicating technologies - two recent phenomena that have been addressed by courts in several jurisdictions. ${ }^{2}$ In contrast, fierce disputes have characterized the application of the doctrine of exhaustion in the context of international trade with respect to the parallel imports of gray market goods - that is, genuine (originally manufactured) products, imported into a country from unauthorized third party importers after their first authorized sale by the IP owners abroad. ${ }^{3}$ The surge in global trade over the past decades has heightened these disputes, driven primarily by the concerns expressed by IP owners against the arbitrage of consumer goods from low-cost to high-cost jurisdictions. Although IP owners are interested in the benefits of free trade in reducing manufacturing costs and decreasing tariffs, quotas, and other trade restrictions, they generally oppose gray market goods because of the competition that these goods create in the high cost domestic markets where they are imported, and the resulting loss of profits in those markets. ${ }^{4}$

To date, not surprisingly, there has been no international agreement on the type of exhaustion doctrine that countries have to follow. Article 6 of the Agreement on Trade-Related Aspects of Intellectual Property Right (the TRIPS Agreement) emphasizes this point, stating that "nothing in this Agreement shall be used to address the issue of the exhaustion of intellectual property rights'. ${ }^{5}$ Left to their discretion, countries tend to adopt the national policy that best promotes their national interests. This includes consideration of the following: the interests of IP owners, national and foreign, who desire control of the cross-border trade of their products, and the ability to set prices and exercise price discrimination in different jurisdictions; the interests of third party importers to sell and distribute goods lawfully purchased abroad; the interests of intermediaries, retailers, and other distributors to distribute goods lawfully acquired from parallel importers; the interests of consumers to access a higher number of goods, likely at lower prices, in national markets thanks to parallel imports; the interests of national governments in promoting local IP-intensive industries by protecting these industries from the additional competition of parallel imports; and the interests of national governments in increasing competition in the national market by opening it up to parallel imports.

Generally, based on the individual balance of these interests in a given national jurisdiction, countries adopt one of three approaches regarding the treatment of

2. Capitol Records, LLC v ReDigi Inc., 934 F. Supp. $2 d 640$ (S.D.N.Y 2013); Case C-128/11, UsedSoft GmbH v Oracle Int'l Corp., 2012 E.C.R. I-00000; Bowman v Monsanto Co., 133 S.Ct. 1761 (2013); Case No. C-428/09, Monsanto v Cefetra, 2010 E.C.R. I-09961.

3. For a detailed analysis and summary of the relevant debates, see the contributions in Irene Calboli and Ed Lee (eds), Research Handbook on Intellectual Property Exhaustion and Parallel Imports (2016); see also Vincent Chiappetta, 'The Desirability of Agreeing to Disagree: The WTO, TRIPS, International IPR Exhaustion and a Few Other Things' (2000) 21 Mich. J. Int'1 L. 333.

4. See Irene Calboli, 'Market Integration and (the Limits of) the First Sale Rule in North American and European Trademark Law' (2011) 51 Santa Clara L. Rev. 1241 [hereinafter Calboli, 'Market Integration'].

5. Agreement on Trade-Related Aspects of Intellectual Property Rights, April 15, 1994, Marrakesh Agreement Establishing the World Trade Organization, Annex 1C, Legal Instrument - Result of the Uruguay Rounds Vol. 31, 33 I.L.M. 83, 1869 U.N.T.S. 299 (1994), art 6 [hereinafter TRIPS]. 
domestic IP exhaustion rules: international, national, or regional exhaustion. ${ }^{6}$ Under the principle of international exhaustion, the rights of IP owners to control the further distribution of a good or batch of goods, exhaust after the first sale of the goods regardless of the country where this first sale has occurred. Undoubtedly the friendliest approach for international trade, under this system parallel imports are considered to be lawful in the country of importation. In contrast, under the principle of national exhaustion, the rights of IP owners are exhausted after the first sale of a good or batch of goods, but only if this first sale has occurred in the national territory. This regime is the least friendly for international trade, and permits IP owners to stop parallel imports at the border or legitimately seize products after importation as IP infringements, even though these are genuine goods. Finally, under the principle of regional exhaustion, a compromising solution between the international and regional exhaustion, the rights of IP owners are exhausted after the first sale of a good or batch of goods, but only if the sale has occurred in one of the member countries of a regional organization that follows this principle as a common rule for all members. Under this system, the import of products originating from third countries remains unlawful and can be stopped as infringement. To date, this approach is the common policy adopted by EU Member States.

Regardless of the silence of Article 6 of TRIPS, and the possibility of nation states to select their preferred national policies on IP exhaustion, the inherent tension between the enforcement of national IP rights and the choice of domestic rules on IP exhaustion becomes particularly problematic when it relates to regional organizations. In particular, the objective of these organizations is (theoretically) primarily that of promoting the free movement of goods within the territory of the organizations. ${ }^{7}$ Yet, the adoption of one approach on exhaustion versus another (notably international versus national versus regional exhaustion), directly translates to permitting or not permitting the cross-border trade of parallel imports. In particular, anything other than a consistent system of regional exhaustion across all members of a regional organization translates to the prohibition of cross-border parallel imports. In turn, the domestic enforcement of national IP rights is likely to become a barrier to legitimate regional trade as parallel imports of genuine goods may be forbidden in some, or all, members of the organization. In this respect, it was precisely the need to create an internal market where all goods could freely flow that brought the EU to adopt a common approach on the issue of IP exhaustion as a matter of EU law. In the remainder of this article, I compare the current position adopted by the EU with those of NAFTA and ASEAN, and I highlight some of the reasons for the existing differences among these organizations. Due to the limited scope of this article, my analysis focuses primarily on the regional treatment of IP exhaustion and does not elaborate on the additional restrictions that can be imposed through contractual restraints on product distribution and resale.

\section{REGIONAL INTEGRATION 'PLUS': FREE MOVEMENT OF GOODS IN THE EU/EEA}

Since the signing of the Treaty establishing the European Economic Community (EEC or Community) in 1957, the primary objective of the members of the EEC (now the EU) has been the creation of an integrated European market where goods, services, people,

6. See, eg, Calboli, 'Market Integration', supra (n 4), at 1252-6.

7. Ibid. 
and capital could move without restrictions. ${ }^{8}$ Accordingly, the European Parliament, the European Commission (EC), and the CJEU - the European Court of Justice (ECJ) as it was then known - have balanced the protection of IP rights with the primary objective of promoting the free movement of goods in the internal market. ${ }^{9}$ As I have illustrated in detail before, this has resulted in the development of a system of region-wide exhaustion - referred to as Community-wide exhaustion - where all IP rights are exhausted with respect to the territory of the EU after the first sale of a product or batch of products, in the EU; thereafter, those products can freely circulate within the internal market. ${ }^{10}$

Still, the harmonization of national laws on IP exhaustion in the EU was a lengthy process. Even though the ECJ promoted free movement of goods and consistently overruled national laws acting as a barrier to trade, the EU/EEA rule on IP exhaustion did not reach full harmonization until the early 1990 s, three decades after the creation of the EEC. In particular, the ECJ initially turned to the competition law provisions of the Treaty on the Functioning of the European Union (TFEU) - then the Treaty Establishing the European Economic Community (EEC Treaty) - to declare attempts to block the free movement of goods across Member States as "incompatible with the common market'. ${ }^{11}$ Starting in the 1970s, the ECJ relied on the principle of free movement of goods in Articles 34 and 36 of the EEC Treaty to permit the free movement of goods within the EU as, at that time, these provisions of the EEC Treaty came into effect. Article 34 of the EEC Treaty, today Article 34 of the TFEU, prohibits quantitative restrictions on importation between Member States and other measures having an 'equivalent effect', ${ }^{12}$ whereas Article 36 states that domestic laws should not provide a means of 'arbitrary discrimination or a disguised restriction of trade between Member States'. ${ }^{13}$

Today, Articles 34 and 36 remain the applicable provisions to the exhaustion of patented goods within the EU. Notably, the distribution of a patented good by the consent of the patent owner into the market of any EU Member State exhausts the rights of

8. Consolidated Version of the Treaty on the Functioning of the European Union, March 30, 2010, 2010 O.J. (C 83) [hereinafter TFEU] as amended following the entering into force of the Treaty of Lisbon on December 1, 2009. Treaty of Lisbon, December 13, 2007, 2007 O.J. (C 306). 9. On the historical tension between the protection of intellectual property and the free movement of goods in the EU, see Friedrich-Karl Beier, 'Industrial Property and the Free Movement of Goods in the Internal European Market' (1990) 21(4) I.I.C. 131; Herman Cohen Jehoram, 'Harmonising Intellectual Property Law Within the European Community' (1992) 23 I.I.C. 622. 10. For a detailed analysis see Irene Calboli, 'Trademark Exhaustion in the European Union: Community-Wide or International? The Saga Continues' (2002) 6 Marq. Intell. Prop. L. Rev. 47, 53-9 [hereinafter Calboli, 'Trademark Exhaustion in the EU']; Irene Calboli, 'Reviewing the (Shrinking) Principle of Trademark Exhaustion in the European Union (Ten Years Later)' (2012) 16 Marq. Intell. Prop. L. Rev. 257 [hereinafter Calboli, 'Reviewing Trademark Exhaustion'].

11. See TFEU, supra (n 8), arts 101-102. The ECJ applied these provisions in Joined Cases 56 \& 58/64, Costen \& Grunding v EC Comm'n, 1966 E.C.R. 299; Case 24/67, Parke Davis v Centrafarm, 1968 E.C.R. 55; Case 40/70, Sirena v Eda, 1971 E.C.R. 69.

12. TFEU, supra (n 8), art 34 ('[q]uantitative restriction on imports and all measures having equivalent effect shall be prohibited between Member States').

13. Ibid. at art 36 (EU Member States can prohibit or restrict 'imports, exports or goods in transit' based upon 'public morality, public policy or public security; the protection of health and life of humans, animals or plants; the protection of national treasures possessing artistic, historic or archaeological value; or the protection of industrial and commercial property', but these prohibitions 'shall not, however, constitute a means of arbitrary discrimination or a disguised restriction on trade between Member States'). 
distribution within the EU. ${ }^{14}$ There are two exceptions to this principle. First, exhaustion does not apply if the goods are produced under a compulsory license, as compulsory licensed goods cannot be exported under Article 31 of TRIPS. ${ }^{15}$ Second, exhaustion does not apply if the product is a patented pharmaceutical manufactured for the purpose of marketing approval rather than for commercialization. ${ }^{16}$ Medicines manufactured for such an approval patent are not subject to exhaustion because they have been produced for regulatory approval purposes only, thus the patent owner has not yet obtained any profit from the initial distribution of the patented product. Articles 34 and 36 also apply to possible contractual limitations against further distribution of patented products. In particular, these limitations may be in conflict with Article 34 and be void if they restrict or prevent importation into and distribution within another EU Member State.

Articles 34 and 36 also initially applied to the exhaustion of trademark rights within the EU. In a series of leading cases, the ECJ clarified that the primary purpose of trademark protection was to indicate the products' commercial origin; thus, there was no reason to prevent the free circulation across Member States of genuine goods identified by marks controlled by the same companies in each Member State. ${ }^{17}$ Only when the mark does not share a common origin or the quality of the products have been changed without the consent of trademark owners, is it possible to block parallel imports within the EU. ${ }^{18}$ In addition, to further promote free movement and prevent product discrimination, the ECJ developed the principle that a Member States could not "prohibit the sale in its territory of a product lawfully produced and marketed in another Member State even if the product is produced according to technical or quality requirements which differ from those imposed on its domestic products'. ${ }^{19}$ This principle, known as 'mutual recognition' was and remains fundamental to guaranteeing an effective free movement of goods across EU Member States.

In the late $1980 \mathrm{~s}$, the principle of Community-wide exhaustion of trademark rights was codified in the First Council Directive 89/104/EEC, later replaced by Directive $2008 / 95$ and more recently replaced by Directive $2015 / 2436 .^{20}$ The provision was

14. Case15/74, Centrafarm v Sterling Drugs, [1974] E.C.R. 1147; Case 187/80, Merck \& Co. v Stephar, [1981] E.C.R. 2063.

15. Case 19/84, Pharmon BV v mHoechst Ag, [1985] E.C.R. 2281.

16. Case C-316/95, Generics v Smith Kline \& French Laboratories, [1997] E.C.R. I-3929.

17. In Case 78/70, Deutsche Grammophon Gesellschaft mbH v Metro-SB-Grossmarket GmbH, 1971 E.C.R. 487, the ECJ distinguished between the 'existence' and the 'exercise' of intellectual property rights and stated that the 'exercise' should be consistent with EU law and protect only the 'specific subject matter' of the right.

18. On the principle of 'common origin', compare Case 192/73, Van Zuylen Freres v Hag AG, 1974 E.C.R. 731, with Case 119/75, Terrapin Ltd. v Terranova Industrie C.A. Kapferer \& Co, 1976 E.C.R. 1039; Case C-10/89, CNL-Sucal v Hag AG, 1990 E.C.R. I-3711; and Case C-9/93, IHT Internationale Heiztechnik GmbH v Ideal-Standard GmbH, 1994 E.C.R. I-2782.

19. Commission Communication No. C 256/2, Communication from the Commission concerning the consequences of the judgment given by the Court of Justice on 20 February 1979 in Case 120/78 ('Cassis de Dijon'), 1980 O.J. (C 256) 2, 2-3 (EC). The ECJ developed the principle of 'mutual recognition' in Case 120/78, Rewe-Zentral AG v Bundesmonopolverwaltung fur Branntwein, 1979 E.C.R. 649 (Cassis de Dijon).

20. First Council Directive 89/104/EEC of December 21, 1988 to Approximate the Laws of the Member States relating to Trademarks, [1989] O.J. L40/1, art 7(1) [hereinafter 1989 Directive], later amended by Trademark Directive 2008/95/EEC of October 22, 2008, [2008] O.J. L299/25, art 7(1) [hereinafter 2008 Directive], and later replaced by Trademark Directive (EU) 2015/2436, [2015] O.J. L336/1, art 15(1) [hereinafter TMD 2015]. 
repeated verbatim in the Council Regulation EC/40/94, later replaced by Council Regulation 207/2009, and now replaced by EU Trademark Regulation 2017/1001 (EU Trademark Regulation). ${ }^{21}$ The adoption of the Agreement for the European Economic Area (EEA) of May 2, 1992, extended this principle to the European Free Trade Agreement (EFTA) countries joining the EEA (Norway, Iceland, and Liechtenstein). ${ }^{22}$ In the years following the adoption of Directive 89/104/EEC, the ECJ clarified that Community-wide exhaustion is the only principle applicable within the EU/EEA, ${ }^{23}$ against the arguments that it was simply a minimum standard. ${ }^{24}$ However, under EU law, there may be 'legitimate reasons' for IP owners 'to oppose further commercialization of the goods' within the EU/EEA. ${ }^{25}$ In particular, either of the following may constitute 'legitimate reasons' against parallel trade within the EU/EEA: unauthorized repackaging and relabeling of genuine products when this may lead to consumer confusion or provoke unfair detriment to the reputation of a mark; ${ }^{26}$ or a licensee's breach of a contract clause prohibiting selling the products in discount stores if sales in discount stores could affect the image and reputation of the marks. ${ }^{27}$

Early ECJ decisions related to the exhaustion of copyrights also referred to Articles 34 and 36 of the TFEU. ${ }^{28}$ Efforts to harmonize copyright laws across the EU subsequently resulted in the adoption of the principle of Community-wide exhaustion in Directive 2001/29/3EC in the harmonization of certain aspects of copyright and related rights in the information society (the 'InfoSociety Directive') ${ }^{29}$ The principle of exhaustion in the InfoSociety Directive is applicable also to computer programs, including software and games. ${ }^{30}$ In addition, Directive 2006/1 15/EC on rental rights, lending rights, and certain rights related to copyright, repeats the same provision with respect to the right of distribution of: performers, with respect to the fixation of their performances; phonogram producers, with respect to their phonograms; producers of

21. Council Regulation 40/94, December 20, 1993 on the Community Trade Mark, 1994 O.J. (L 011) 1 (EC), replaced by Council Regulation 207/2009, 2009 O.J. (L 78) 1 (EC), and now replaced by EU Trademark Regulation (EU) 2017/1001 of the European Parliament and of the Council of 14 June 2017 on the EU trade mark, 2017 O.J. L 154/1 (EC).

22. Protocol to the Agreement on the European Economic Area, January 3, 1994, 1994 O.J. (L 1) Annex XVII, art 2(1) extended the effect of Article 7 of the Trademark Directive to the EEA from January 1, 1994.

23. See, eg, Nicholas Shea, 'Does the First Trade Marks Directive Allow International Exhaustion of Rights?' (1995) 10 E.I.P.R. 463, 463.

24. For a detailed reconstruction of the debates on this issue following the adoption of the 1989 Directive, see Calboli, 'Trademark Exhaustion in the EU', supra (n 10), at 60-66.

25. 1989 Directive and 2008 Directive, supra (n 20), art 7(2); 2015 Directive, art 15(2).

26. Calboli, 'Reviewing Trademark Exhaustion', supra (n 10), at 261-2.

27. Case C-59/08, Copad SA v Christian Dior Couture SA, 2009 E.C.R. I-03421; Case C-558/08, Portakabin Ltd, Portakabin BV v Primakabin BV, 2010 E.C.R. I-0000; Case C-127/09, Coty Prestige Lancaster Group GmbH v Simex Trading AG, 2010 E.C.R. I-0000.

28. Case 78/70, Deutsche Grammophone v Metro SB, [1971] E.C.R. 487; Cases C-55/80 and C-7/80, Musik-Vertrieb Membran and K-tel Int. v GEMA, [1981] E.C.R. 147. But see Case 156/86 Warner Brothers v Christiansen, [1988] E.C.R. 2605; Case C-341/87, EMI Electrola v Patricia, [1989] E.C.R. 79.

29. Directive 2001/29/EC of the European Parliament and of the Council of 22 May 2001, 2001 O.J. (L 167) 10 (EC), art 4(2) [hereinafter InfoSociety Directive].

30. This point is specifically addressed in Directive 2009/24/EC, of the European Parliament and of the Council of 23 April 2009, 2009 O.J. (L 111) 16 (EC), art 4(2), which repealed and replaced Directive 91/250/EEC (also referred to as the 'Software Directive'). 
the first fixation of films, with respect to the original and copies of their films; and broadcasting organizations, with respect to the fixation of their broadcasts. ${ }^{31}$ Hence, exhaustion does not apply where the copyrighted article has been modified subsequent to its initial marketing such that the article can be considered a new reproduction of the original article. ${ }^{32}$ In addition, not all exclusive rights are exhausted under EU law. In particular, the InfoSociety Directive explicitly denies the application of exhaustion to the right of communication to the public, and the right to make a copyrighted article available to the public. ${ }^{33}$ Similarly, Directive 2006/115/EC provides that the 'right to authorize or prohibit the rental and lending of originals and copies' shall 'not be exhausted by any sale or other act of distribution of originals and copies of copyright works and other subject matter' ${ }^{34}$ The InfoSociety Directive also excludes from the application of exhaustion 'services and on-line services in particular'. ${ }^{35}$

\section{REGIONAL INTEGRATION 'LIGHT': (LIMITED) FREE MOVEMENT OF GOODS IN NAFTA}

The adoption of NAFTA in 1994 marked the creation of a free trade area covering Canada, the US, and Mexico. ${ }^{36}$ In practice, one of the main drivers for the US and Canada to join NAFTA was to manufacture products in Mexico, a lower-costs country, and later reimport these products at a lower tariff rate into their national territories. Mexico, on the other hand, joined the agreement primarily because of the foreign direct investment (FDI) that it would receive from US and Canadian firms. Negotiated in parallel with, and adopted two years prior to the implementation of TRIPS, NAFTA was the first free trade agreement including detailed IP provisions. ${ }^{37}$ In particular, Article 1701 of NAFTA requires that NAFTA Members provide 'adequate and effective protection and enforcement of intellectual property rights' in each Party's territory, ${ }^{38}$ even though these measures should not 'become barriers to legitimate trade'. ${ }^{39}$ Similar to TRIPS, NAFTA remained silent on the treatment of exhaustion, leaving its Members free to adopt their preferred position with respect to their national rules on parallel imports. ${ }^{40}$ As I describe below, NAFTA Members today follow the same national position with respect to trademark exhaustion and a

31. Directive 2006/115/EC of the European Parliament and of the Council of 12 December 2006, 2006 O.J. (L 376) 28 (EC), art 9(2).

32. Art \& Allposters Int'l BV v Stichting Pictoright C-419/13, [2015] E.C.D.R. 7.

33. InfoSociety Directive, supra (n 29), art 3(3).

34. Directive 2006/115/EC, supra (n 31), arts 1(2) and 9(2).

35. InfoSociety Directive, supra (n 29), Recital 29.

36. North American Free Trade Agreement, U.S.-Can.-Mex., art 1701(1), December 17, 1992 , 32 I.L.M. 289 (1993) [hereinafter NAFTA].

37. Ibid, at ch. 17. NAFTA was negotiated alongside the negotiations that led to the creation of the World Trade Organization (WTO) and the adoption of TRIPS. Thus, NAFTA provisions are largely modeled after TRIPS.

38. NAFTA, supra (n 36), art 1701(1).

39. Ibid; see also, eg, George Y Gonzalez, 'An Analysis of the Legal Implications of the Intellectual Property Provisions of the North American Free Trade Agreement' (1993) 34 Harv. Int'1 L.J. 305, 306.

40. NAFTA does not mention or address the issue of exhaustion in the language of Chapter Seventeen of NAFTA. NAFTA, supra (n 36), ch. 17. 
quite similar national position regarding copyright exhaustion. The three countries differ over their domestic rules on patent exhaustion.

In particular, international exhaustion is the currently applied trademark exhaustion rule in all NAFTA member countries. In Canada, parallel imports of trademarked goods have traditionally been permitted, so long as the same or affiliated owners control the marks both inside and outside Canada (ie the marks share a common origin). ${ }^{41}$ Canadian courts occasionally objected to the importation of goods that were materially different from the products authorized in the Canadian market - for example, when the goods had been damaged and the distributor had replaced the original labels placed on the goods ${ }^{42}$ or when the formulation of the imported goods was different than the products sold nationally. ${ }^{43}$ Still, Canadian courts generally allow parallel imports when the importers use labels to disclaim the fact that the products may be of different quality in order to prevent consumer confusion. ${ }^{44}$ The US position is virtually identical: parallel imports are allowed when the marks share a common business origin. ${ }^{45}$ Similar to Canadian courts, US courts have halted products when they 'differ materially' from the goods authorized for sale in the US. ${ }^{46}$ Yet, under the US Customs Service Regulations, materially different products can still be lawfully imported when importers properly label the goods to avoid confusion. ${ }^{47}$ Finally, parallel imports of trademarked goods are considered 'legitimate' under the Mexican Industrial Property Law, so long as the owners of the mark inside and outside Mexico are 'the same person or members of the same joint economic interest group, or their licensees or sublicensees' ${ }^{48}$ To date, Mexican courts have not halted or expressed concern as to the importation of materially different parallel imports into Mexico because of potential consumer confusion. ${ }^{49}$

41. Wilkinson Sword (Can.) Ltd. v Juda, [1966] 51 C.P.R. 55 (Can.); Wella Canada Inc. v Pearlon Products Ltd., [1984] 4 C.P.R. 3d 287 (Can. Ont. H.C.J.); Coca-Cola Ltd. v Pardham, [1999] 85 C.P.R. 3d 489 (Can. F.C.A.).

42. Dupont of Canada Ltd. v Nomad Trading Co., [1968], 55 C.P.R. 97 (Can. Que. S.C.).

43. H.J. Heinz Co. of Canada Ltd. v Edan Foods Sales Inc., [1991], 35 C.P.R. 3d 213 (Can. F.C.T.D.) (finding potential consumer confusion between the formulation of ketchup in Canada and the United States because of the different tomatoes used in the respective products).

44. Consumers Distributing Co. v Seiko Time Canada Ltd. (1984), 1 C.P.R. 3d 1, 24-25 (Can. S.C.C.) (noting that the notice affixed to the products neutralized the significance of any difference in the products' warranties); see also Nestle Enterprises Ltd. v Edan Sales Inc., [1991] 37 C.P.R. 3d 480 (Can. F.C.A.).

45. K-Mart Corp. v Cartier, Inc., 486 U.S. 281, 289 (1988) (indicating that the 'extraordinary protection' afforded by the Tariff Act $\S 526$ is exclusively for domestic US trademark owners that have no corporate affiliation with the foreign manufacturer).

46. Lever Bros. Co. v United States, 877 F.2d 101 (D.C. Cir. 1989) and Lever Bros. Co. v United States, 981 F.2d 1330 (D.C. Cir. 1993) (ruling that when a mark is applied to physically different goods, the mark is not 'genuine' for the American consumer). See also Societe Des Produits Nestle, S.A. v Casa Helvetia, Inc., 982 F.2d 633, 639 (1st Cir. 1992).

47. 19 C.F.R. $\$ 133.23$ (b) (U.S.) ('Goods determined by the Customs Service to be physically and materially different ... shall not be detained ... where the merchandise or its packaging bears a conspicuous and legible label designed to remain on the product until the first point of sale ...').

48. Mexican Industrial Property Regulations and Reglamento de la Ley de la Propiedad Industrial [Regulation on the Industrial Property Law], Diario Oficial de la federación [DO], November 18, 1994, art 54 (Mex.) [hereinafter Mexican Industrial Property Regulations].

49. Although courts have not considered the repackaging or relabeling of gray market products, these instances could likely fall under the prohibition of Article 213 of the Mexican 
At large, NAFTA Members follow international exhaustion also in copyright law, even though the regulation of copyright exhaustion proves more complex, and not all products, nor the rights granted to copyright owners, follow the same regime. Notably, Canada applies national exhaustion regarding the distribution of books, ${ }^{50}$ even though this prohibition concerns only physical copies of literary works and applies where there is an exclusive distributor of the book in Canada. ${ }^{51}$ In contrast, the Canadian Copyright Act offers a more liberal approach to the parallel importation of other copyrighted products $^{52}$ in the instances where the owner of a copyright is the same in Canada as in the country where the works are created and first distributed. ${ }^{53}$ In addition, the 2012 Copyright Modernization Act created a 'first sale' right in a context where no distribution rights exist. ${ }^{54}$ No decision has been adopted, to date, on this point in Canada. In the US, international copyright exhaustion has become the national rule since the 2013 decision in Kirtsaeng v John Wiley \& Sons, Inc. ${ }^{55}$ The decision in Kirtsaeng clarified the language of the 1976 US Copyright Act, which states, on one side, that copyright owners cannot control the transfer of copyrighted works 'lawfully made under this title' after their first sale; ${ }^{56}$ and on the other side, that 'the importation into the United States' of a copyrighted work acquired outside 'without the authority of the [copyright] owner' is 'an infringement of the exclusive right [of] distribut[ion]' ${ }^{57}$ Since Kirtsaeng, it has been clarified that exhaustion applies equally to products 'lawfully made' in the US and in foreign countries. ${ }^{58}$ Under US law, not all rights granted to copyright owners are exhausted. In particular, copyright exhaustion does not apply to the right of 'rental, lease, or lending'. ${ }^{59}$ Similarly, copyright owners retain the rental right in copyrighted software and phonorecords even after a first sale ${ }^{60}$ Mexico follows international exhaustion, even though the Mexican Federal Copyright Law does not expressly address the issue. Yet, in the absence of an express right to prevent the importation of legitimate copies of copyrighted works, it has been interpreted that parallel imports are legally permitted in Mexico. ${ }^{61}$ However, also under Mexican law, exhaustion does not seem to apply to computer programs and databases after the first sale of the copies. ${ }^{62}$

Industrial Property Law. Ley de Fomento y Protección de la Propiedad Industrial, D.O. 4, June 27, 1991, amended by D.O. August 2, 1994 (Mex.), at art 213(XX and XXI) [hereinafter Mexican Industrial Property Law].

50. Section 27.1, Copyright Act, R.S.C. 1985, c. C-42 (Can.). This provision was introduced in 1999. See Act to Amend the Copyright Act, S.C. 1997, c. 24 (Can.), which became effective on September 1, 1999.

51. As a prerequisite, exclusive distributors and copyright holders must give 'notice of exclusive distributor' as prescribed in the Regulations. Canadian Copyright Act, at Section 4(1) (Can.).

52. Copyright Act, at Section 27(2)(e) (Can.).

53. Ibid.

54. Copyright Modernization Act (S.C. 2012, c. 20) (Can).

55. Kirtsaeng $v$ Wiley, 568 US 519, 133 S. Ct. 1351(2013).

56. 17 U.S.C. $\$ 109$ (a) (U.S.).

57. 17 U.S.C. $\$ 602(a)(1)$ (U.S.).

58. Kirtsaeng, 133 S. Ct. 1358 (supporting that $\S 109$ (a) also applies 'where, as here, copies are manufactured abroad with the permission of the copyright owner').

59. 17 U.S.C. § $106(3)$ (U.S.); 17 U.S.C. \& 109(d) (U.S.).

60. 17 U.S.C. $\$ 109$ (b) (U.S.).

61. Federal Law on Copyright, art 27(IV), Diario Oficial de la Federación [DO], December 5, 1996 (Mex.).

62. Ibid at art 104 . 
Finally, NAFTA Members take a different position on patent exhaustion, even though no statute of the respective countries explicitly addresses the issue. The rule on patent exhaustion in Canada is based on case law. In the 1998 decision in Eli Lilly \& Co v Novopharm Ltd., the Supreme Court of Canada confirmed that when a patentee sells a patented product, the rights of the products exhaust as long as the seller did not impose any restrictions on the subsequent distribution. ${ }^{63}$ Thus, the key inquiry in Canada is not where the goods were first sold, whether in or outside Canada, but whether the product was sold with or without restrictions. ${ }^{64}$ In the US, the position on patent exhaustion was recently changed in favor of international exhaustion by the 2017 Supreme Court decision in Impression Products v Lexmark. ${ }^{65}$ The US Patent Act does not elaborate on the geographical extent of the first sale of a patented process, or a product embodying a patented process. Several decisions by US courts had adopted the position that the sale of an article in a foreign country did not exhaust the US patent. ${ }^{66}$ In its February 2016 decision in the Lexmark case, the US Court of Appeals for the Federal Circuit repeated this position, but the Supreme Court reversed it. Still, the Court did not exclude that contractual restrictions could prevent the import of gray market goods after the decision in Lexmark ${ }^{67}$ Lastly, also under Mexican law, no specific language related to the exhaustion of patent rights is found. Since the rights conferred by a patent cannot be asserted against 'any person who markets, acquires or uses the patented product or the product obtained by means of the patented process, after said product has been lawfully placed on the market', ${ }^{68}$ the majoritarian interpretation of the wording 'the market' is that it only includes 'national market'. ${ }^{69}$

\section{REGIONAL INTEGRATION 'THE ASEAN WAY': FREE MOVEMENT OF GOODS IN WAITING}

ASEAN was established in 1967 with the aim of integrating the ASEAN Members into a regional economic organization. ${ }^{70}$ ASEAN Members have adopted fundamental principles of consensus and non-interference with national policies. ${ }^{71}$ This approach is defined as the 'ASEAN Way'. In addition, ASEAN did not create institutions in charge of developing, administering, or ruling on issues related to ASEAN-focused policies. In 2003, the ASEAN Members resolved to establish an ASEAN

63. Eli Lilly \& Co. v Novopharm Ltd., [1998] 2 S.C.R. 129.

64. Ibid.

65. Impression Products, Inc. v Lexmark Int'l, Inc., 581 U.S. 1523 (2017).

66. Boesch v Graff, 133 U.S. 697 (1890); Jazz Photo Corp. v Int'l Trade Commission, 264 F.3d 1094 (Fed. Cir. 2001); Jazz Photo Corp. v Int'l Trade Commission, 264 F.3d 1094 (Fed. Cir. 2001); Lexmark Int'l, Inc. v Impression Prods. Inc., 816 F.3d 721, 771 (Fed. Cir. 2016).

67. Impression Products, Inc. v Lexmark Int'l, Inc., 581 U.S. 1523 (2017).

68. Mexican Industrial Property Law, supra (n 49), art 22.

69. See Carlos M Correa and Juan I Correa, 'Parallel Imports and the Principle of Exhaustion of Rights in Latin America', in Irene Calboli and Ed Lee (eds), Research Handbook on Intellectual Property Exhaustion and Parallel Imports (Edward Elgar Publishing, Cheltenham, UK and Northampton, MA, USA 2016) 206.

70. The ASEAN Declaration (Bangkok Declaration), Bangkok, Thailand, ASEAN, August 8, 1967.

71. Treaty of Amity and Cooperation in Southeast Asia, Indonesia, ASEAN, February 24, 1976, 2012 O.J. (L 154) 6. 
Community, and in 2007, adopted the ASEAN Charter. ${ }^{72}$ One of the pillars of the ASEAN Community was the creation of the ASEAN Economic Community (AEC), which was launched in $2015 .^{73}$ The AEC aims to integrate ASEAN Members' markets into a single market that comprises the free movement of goods, services, investment, capital, and skilled labor. ${ }^{74}$ The foundation of the ASEAN market can be traced to the Declaration on the ASEAN Economic Community Blueprint. ${ }^{75}$ In 1992, ASEAN Members also signed an Agreement on the Common Effective Preferential Tariff Scheme for the ASEAN Free Trade Area ${ }^{76}$ (AFTA) in order to foster regional economic integration and eliminate tariff and non-tariff barriers. ${ }^{77}$

As part of the process of ASEAN integration, in 1995 ASEAN Members adopted the ASEAN Framework Agreement on Intellectual Property Cooperation ${ }^{78}$ aiming at establishing cooperation in several IP-related areas. ${ }^{79}$ To date, this cooperation has focused primarily on administrative matters such as interoperability between and assistance with domestic procedures adopted for patent and trademark searches, and the creation of regional databases. ${ }^{80}$ Hence, IP laws of ASEAN Members are largely harmonized, as all ASEAN Members are part of the World Trade Organization (WTO) and have aligned their national laws with the principles set by TRIPS. ${ }^{81}$ Still, TRIPS only provides for common minimum standards, and is silent on the national treatment of the exhaustion of IP rights. In the absence of any fixed provision or guideline, ASEAN Members remain free to decide what system of exhaustion they prefer to adopt domestically based on their respective national interests. To date, this has led to inconsistent national approaches in this area, and in turn to a non-effective free movement of IP-protected goods across ASEAN.

72. Declaration of ASEAN Concord II (Bali Concord II), ASEAN, October 7, 2003; The ASEAN Charter, ASEAN, November 20, 2007.

73. ASEAN Members committed to accelerate the establishment of the ASEAN Economic Community in the Cebu Declaration on the Acceleration of the Establishment of an ASEAN Community by 2015 .

74. For a detailed analysis of the creation of the AEC, see Stefano Inama and Edmund W Sim, An Institutional and Legal Profile (Cambridge University Press 2015).

75. ASEAN, Declaration on the ASEAN Economic Community Blueprint, §§ 11, 13, \& 14 (2008).

76. Agreement on the Common Effective Preferential Tariff (CEPT) Scheme for the ASEAN Free Trade Area (AFTA), art 5, January 28, 1992 [hereinafter CEPT-AFTA].

77. ASEAN Trade in Goods Agreement (ATIGA), art 8(d), February 26, 2009.

78. ASEAN Framework Agreement on Intellectual Property Cooperation, December 15, 1995, WIPO Lex. No. TRT/ASEAN-IP/001.

79. Ibid at art 3(1).

80. See ASEAN, Hanoi Plan of Action, adopted at the Sixth ASEAN summit in 1998 in Vietnam, 15 December 1997; Intellectual Property Rights Action Plan 2004-2010, as part of Vientiane Action Programme 2004-2010, 29 November 2004; Work Plan for ASEAN Cooperation on Copyright, 2006; Intellectual Property Rights Action Plan 2011-2015; Intellectual Property Rights Action Plan 2011-2015.

81. TRIPS, supra (n 5), art 6. With the exception of Myanmar, all ASEAN Members are signatories to the Paris Convention for the Protection of Industrial Property and to the Berne Convention for the Protection of Literary and Artistic Works, the two most relevant international agreements harmonizing national IP laws pre-TRIPS, which have also considerably harmonized substantive laws on IP across all members. See Paris Convention for the Protection of Industrial Property, March 20, 1883, as revised July 14, 1967, 21 U.S.T. 1583, 828 U.N.T.S. 305; The Berne Convention for the Protection of Literary and Artistic Works, September 9, 1886, as revised July 24, 1971, and as amended September 28, 1979, 102 Stat. 2853, 1161 U.N.T.S. 3. 
In particular, with respect to trademark exhaustion, ASEAN Members can be divided into three separate groups: countries without a specific rule on exhaustion; countries following national exhaustion; and countries following international exhaustion. Among the ASEAN Members in the latter group, some do not follow international exhaustion when the products at issue are of materially different quality. Furthermore, ASEAN Members do not adopt a principle similar to the EU principle of mutual recognition.

Notably, Indonesia ${ }^{82}$ and Brunei Darussalam have not yet adopted any relevant statutory provision on trademark exhaustion and no judicial decision on the issue can be found so far in either country. ${ }^{83}$ Thus, it could be supported that these countries would admit parallel imports from other ASEAN Members, and in general from foreign jurisdictions; but this remains an assumption based on the lack of any rules. Myanmar also does not have any provision on trademark exhaustion, as Myanmar does not currently have a law on trademarks. ${ }^{84}$ On the other hand, Cambodia and Lao PDR adopt national trademark exhaustion, even though neither country's laws specify that parallel imports are forbidden. ${ }^{85}$ The remaining ASEAN Members follow international trademark exhaustion. In particular, Singapore ${ }^{86}$ and Vietnam have adopted specific provisions establishing the principle of international trademark exhaustion as their respective domestic rules. ${ }^{87}$ Prior to 2009 , Vietnam adopted national exhaustion, although the National Office of Industrial Property of Vietnam 'occasionally' permitted the imports of products manufactured by third countries as 'an ad hoc policy', for example in regard to the importing of motorbikes from China under trademark licensing agreements. ${ }^{88}$ The Philippines also follows international exhaustion, de facto, since the Philippines has not included a specific provision in this sense. ${ }^{89}$ Finally, Malaysia and Thailand follow international exhaustion as a

82. Indonesia Law No. 15 of August 1, 2001, regarding Marks, art 1(13), WIPO Lex. No. ID046 (Indonesia).

83. Trade Marks Act (Chapter 98, Laws of Brunei Darussalam, Revised Edition 2000) (BN008) (Brunei).

84. A draft trademark law has been approved by the Myanmar's Attorney General Office and has been under review in the Parliament of Myanmar since 2014. Article 41 adopts the principle of international exhaustion while Article 42 'prevents the importation of goods which have been altered after their initial sale. See International Trademark Association, Comments by the International Trademark Association on the Myanmar Draft Trademark Law §§ 41, 42.

85. Law Concerning Marks, Trade Names and Acts of Unfair Competition of the Kingdom of Cambodia, NS/RKM/0202/006, February 7, 2002, art 11(c) (Cambodia); Law No. 01/NA of December 20, 2011, on Intellectual Property (as amended), December 20, 2011, art 57(3) lit.1 (Lao PDR).

86. Singapore Trade Marks Act (Chapter 332, 2005 Revised Edition), art 29(1) (Sing.).

87. Law No. 50/2005/QH11, of November 29, 2005, on Intellectual Property Law (promulgated by the Order No. 28/2005/L-CTN of December 12, 2005, of the President of the Socialist Republic of Vietnam), November 29, 2005, art 125 (Vietnam). This law was amended in 2009 by Law No. 36/2009/QH12 on June 19, 2009, amending and supplementing a Number of Articles of the Law on Intellectual Property (promulgated by the Order No. 12/2009/L-CTN on June 29, 2009 of the President of the Socialist Republic of Vietnam), June 19, 2009 (Vietnam). However, the trademark exhaustion provision, Article 125, remains unchanged.

88. See Pham Duy Nghia, 'Exhaustion and Parallel Imports in Vietnam', in Christopher Heath (ed), Parallel Imports in Asia (Wolters Kluwer 2004) 88.

89. Intellectual Property Code of the Philippines (Republic Act No. 8293), June 6, 1997 (Phil.) as amended by Implementing Rules and Regulations of the Republic Act No. 9502 of 2008, July 4, 2008 (Phil.) as amended by Republic Act No. 10372, entitled 'An Act 
result of a national case law ruling on the legality of parallel imports into the respective national territory of these countries. ${ }^{90}$

With respect to the exhaustion of patent rights, ASEAN Members present an inconsistent picture. Notably, ASEAN national policies on patent exhaustion can be divided as follows: countries that adopt a system of international exhaustion through legislative provisions or case law; countries that adopt a system of national exhaustion based on legislative provisions; countries that do not have a specific rule on exhaustion; and countries that treat pharmaceutical products differently for the purpose of patent exhaustion compared to other products.

In particular, Cambodia follows international exhaustion under its Law on the Patents, Utility Model Certificates and Industrial Designs. ${ }^{91}$ A similar position is adopted under the Patents Act of Malaysia, ${ }^{92}$ and the Intellectual Property Law of Vietnam. ${ }^{93}$ Singapore also follows international exhaustion, and applies the concept of 'deemed consent', according to which any condition restricting the resale of the product outside the territory of manufacturing or first sale shall be disregarded. ${ }^{94}$ However, Singapore does not allow imports of patented pharmaceuticals if the products have not been previously sold or distributed in Singapore by the patent owner or with her consent ('first mover advantage'). Second, imports can still be blocked when the pharmaceuticals have been imported as a result of a breach in the contract between the patent owner and her licensees, including outside Singapore. ${ }^{95}$ In contrast, the 2016 Patent Law of Indonesia ${ }^{96}$ grants patent owners the exclusive right to prohibit that other parties 'import' the patented products or the products derived from the patented products. ${ }^{97}$ Yet, this provision does not apply to imports of patented pharmaceuticals lawfully marketed outside Indonesia. ${ }^{98}$ Similarly, the Philippine Intellectual Property Code ${ }^{99}$ includes the right to oppose unauthorized imports, ${ }^{100}$ but again this provision does not apply to the imports of pharmaceuticals. ${ }^{101}$ Finally, Brunei, ${ }^{102}$ Lao PDR, ${ }^{103}$ and Thailand do not

Amending Certain Provisions of Republic Act No. 8293, otherwise known as the "Intellectual Property Code of the Philippines", and for other purposes', February 28, 2013, art 166 (Phil.). 90. Trademark Act (Act 175 of 1976, as last amended by Act A1138 of 2002), June 21, 1976, art 70D (Malaysia).

91. Law on Patents, Utility Models and Industrial Designs (2003), art 44 (Cambodia).

92. Patents Act 1983, as amended by the Patents (Amendment) Act 2006, Section 58A (Malaysia).

93. Law on Intellectual Property (No. 50/2005/QH11 of November 29, 2005), art 125(2)(b) (Vietnam).

94. Patents Act (Ch. 221, 2005 Rev. Ed.), Section 66(2)(g) (Sing.).

95. Ibid at Section 66(3).

96. Law of the Republic of Indonesia No. 13 of July 28, 2016, on Patents (Indonesia).

97. Ibid at art 19(1)-(2) and art 160 .

98. Ibid at art 167. This exception is based directly on the need 'to ensure a reasonable price and satisfy the justice of a pharmaceutical product [that] is necessary for human health'. Ibid at Explanation to art. 167.

99. Intellectual Property Code of the Philippines (Republic Act No. 8293) (1997), as amended by the Republic Act No. 10372 (2013) (Philippines).

100. Ibid at Section 72.

101. Ibid.

102. Constitution of Brunei Darussalam, Order made under Article 83(3), Patents Order (2011) (Brunei).

103. Lao People's Democratic Republic Intellectual Property Laws (Law No. 01/NA of 20 December 2011) (Lao PDR). 
have a specific rule on patent exhaustion. ${ }^{104}$ In these countries, whether the parallel importation of genuine products sold overseas with the proprietors' consent constitutes infringement may depend on the contents of the contracts signed between the parties concerned. In Myanmar, approval is pending on a 2015 Draft Patent Law, even though it remains unclear how the principle of patent exhaustion is addressed in the new law.

Lastly, national rules on copyright exhaustion within ASEAN Members are also inconsistent, and can be divided into the following groups: those following a system of international exhaustion through explicit legislative provisions; those following national exhaustion based on legislative provisions or the interpretation thereof; those not having a specific rule on exhaustion but who could be seen as supporting national exhaustion; and those without a clear, or any, policy.

Singapore is the only country that currently has a clear policy supporting international exhaustion under the Copyright Act of 1987 (as amended in 1994) and according to relevant case law. ${ }^{105}$ In other countries, ambiguous statutory language could also support international exhaustion. In Brunei Darussalam, the Emergency (Copyright) Order of 1999 limits copyright owners' exclusive rights 'to issue copies of the work to the public' ${ }^{106}$ only to 'copies not previously put into circulation, whether in Brunei Darussalam or elsewhere', and not to the subsequent distribution or importation of these copies. ${ }^{107}$ Indonesia's newly revised Copyright Law of 2014 could also be interpreted as supporting a system of international exhaustion. ${ }^{108}$ On the other side, it remains unclear how to interpret Thailand's position under the Copyright Act of 1994, as amended in $2015,{ }^{109}$ as the law does not provide for any specific right to import or distribute the copyrighted work or a copy of it, yet it grants the right of 'communication to the public', which could potentially include the right to distribute the work. ${ }^{110}$ In contrast, national exhaustion seems to be the system of choice under the Cambodian Law on Copyrights and Related Rights of $2003,{ }^{111}$ which grants authors the exclusive rights of national distribution and importation of copyrighted copies into Cambodia for commercial purposes. ${ }^{112}$ The same applies under the Intellectual Property Laws (IP Laws) of 2011 of Lao PDR, ${ }^{113}$ the Intellectual Property Code of the Philippines, ${ }^{114}$ and the Law on Intellectual Property of 2005 of Vietnam. ${ }^{115}$ In Malaysia, the Copyright Act of 1987 , as amended in the Copyright Amendment Act of 1990, also favors a system of national exhaustion. ${ }^{116}$

104. Patent Act B.E. 2522 (1979), as amended by the Patent Act (No. 2) B.E. 2535 (1992) and the Patent Act (No. 3) B.E. 2542 (1999) (Thailand).

105. 2006 Copyright Act, Section 25(3) (Sing). The amendments additionally clarified that the existence of copyright owners' consent is determined without regard to any 'condition as to the sale, distribution or other dealings in the article after its making'. Ibid Section 25(4).

106. Emergency (Copyright) Order 1999 (1999), art 18(1)(b) (Brunei).

107. Ibid.

108. Copyright Law (2014), art 9(1)(e) (Indonesia).

109. Copyright Act of 1994 (Thailand).

110. Ibid, Section 15.

111. Law on Copyrights and Related Rights of 2003 (Cambodia).

112. Ibid, art 21 . Article 23 provides that the 'importation of a copy of work by any natural person, for his/her personal use, can be done without the consent of the author ... or the rightholder'. Ibid.

113. Lao People's Democratic Republic Intellectual Property Laws (2011), art 98 (Lao PDR). 114. Intellectual Property Code of the Philippines 1997, Chapter V, art 177.3 (Philippines).

115. Law No. 50/2005/QH1 1 of November 29, 2005, on Intellectual Property, art 20 (Vietnam). 116. Copyright Act 1987, Section 36(2) (Malaysia). 
Finally, the 1914 Copyright Law of Burma, still the official law in Myanmar, provides that the copyright owner has the power to control the importation of copyrighted articles into Burma, implying a system of national copyright exhaustion. ${ }^{117}$ This position seems confirmed in Myanmar's draft copyright law released in $2015 .^{118}$

\section{COMPARING THE EU/EEA, NAFTA, AND ASEAN: THE NEED FOR CONSISTENT RULES TO PROMOTE FREE MOVEMENT OF GOODS}

As described above, the principle of IP exhaustion is based on the premise that IP rights should not be used to control the distribution of a product or batch of products after their first release into the market. With respect to cross-border trade, the key question remains whether IP rights exhaust only with respect to products that have been distributed in the national market or also in foreign markets, as long as the products are genuine. This inquiry becomes particularly relevant, as I noted in section 2, with respect to the national policies on IP exhaustion that are adopted by the members of regional organizations, as these organization frequently intend to create a higher degree of economic integration among their members and, in several instances, a regionally integrated internal market where goods are allowed to flow without any restrictions. Still, the examples of regional organizations addressed in this article the EU/EEA, NAFTA, and ASEAN - show considerable variations regarding national policies on IP exhaustion. Not surprisingly, these variations result in divergences regarding the effectiveness of the free movement of goods within the respective regional organization.

However, as I noted in the Introduction, not all regional organizations necessarily aim at achieving a full-scale market integration like the one desired by the EEA/EU Members States, and for several different reasons. For example, not all members of a regional organization may desire a high level of market integration due to different national interests, particularly in terms of economic and social policies, as well as level of development, size, and extent of existing agreements with third countries. ${ }^{119}$ In particular, the following factors can play an important role in the assessment of the economic impact of the national exhaustion rules: the extent of current imports and exports, including parallel trade, of a country, with particular attention paid to which countries represent the primary trading partners; the importance of IP protection for particular sectors of the national economy; existing price differences for IP protected goods sold in a country; the amount and impact of transaction costs such as shipping and other distribution-related costs on the final costs of consumer goods; existing trade barriers; and vertical constraints that (otherwise) affect the IP owners' ability to control price discrimination in a country or region. ${ }^{120}$ For these reasons,

117. Copyright Law of Burma of 1914, Section 6 (Myanmar).

118. See, Draft Myanmar Copyright Law Published in Kyemon Newspaper (The Mirror), July 9, 2015, <http://www.eifl.net/sites/default/files/resources/kyemon_mirror_9july2015_key_points. pdf> (accessed January 20, 2018).

119. See, eg, Mattias Ganslandt and Keith E Maskus, 'Intellectual Property Rights, Parallel Imports, and Strategic Behavior', in Keith E Maskus (ed), Intellectual Property, Growth, and Trade (Elsevier Science Ltd 2008) 267-8.

120. National Economic Research Associates (NERA), The Economic Consequences of the Choice of Regime in the Area of Trademarks: Final Report for DG XV of the European Commission (1999) 108-22, previously available at <http://ec.europa.eu/internal_market/ indprop/docs/tm/report_en.pdf $>$ and currently on file with the author. 
choosing a national policy on exhaustion remains a sensitive topic, and not all members of a regional organization may be interested or ready to reach a high level of market integration, including the harmonization of national rules on IP exhaustion. ${ }^{121}$

The analysis of the approaches described in this article exemplifies these considerations and the possible related concerns. As I elaborated in section 3, full-scale economic integration has been the primary objective of the European project since its inception. Under the design of its founding fathers, the EU has historically been driven by functionalist, and then even federalist theories of regional integration. ${ }^{122}$ As a result, EU Member States were required early on to harmonize their national laws, including on IP-related matters and IP exhaustion, as divergences in national rules could create a barrier to intra-EU/EEA trade. The importance of the free movement of goods was directly reflected in the fact that before reaching a full-scale harmonization of laws, the ECJ developed, and EU Member States accepted, the principle of mutual recognition of national standards across all EU Members. Moreover, only very serious concerns relating to health, security, or public policy in member countries can supersede free movement of goods in EU/EEA trade. ${ }^{123}$

Hence, it took several decades from the launching of the EEC in 1957 to reach a fully functioning internal market, which only happened in the 1990s. Here again, the role of the ECJ and the EU Commission was crucial in monitoring the correct integration of EU law into the national laws of Member States. As reported in section 3, the ECJ issued a large number of decisions related to the interpretation of the IP laws, including several decisions on the interpretation and application of the principle of IP exhaustion. ${ }^{124}$ However, while the EU has achieved a high degree of economic integration within the EU/EEA, this full-scale market integration remains confined to the territory of the EU/EEA. Notably, EU/EEA Members are bound to adopt regional exhaustion as the only applicable standard in their laws. In turn, genuine products coming from outside 'Fortress Europe' can be legally stopped at the will of IP owners as IP infringements. ${ }^{125}$ Ultimately, as much as the EU/EEA solution certainly constitutes a stronger and more definite approach to facilitating trade among members of a regional organization, this solution permits (and safeguards) market partitioning outside the EU/EEA. ${ }^{126}$ It also reflects that for the majority of EU/EEA Members, a system facilitating trade intra-EU/EEA and the strengthening of the EU/EEA internal market may be in the best interests of individual Member States, and not only for the regional organization. ${ }^{127}$

In contrast, NAFTA Members never intended to build a NAFTA internal market. As I noted in section 4, the US and Canada joined NAFTA, to a large extent, to facilitate lower-cost manufacturing in Mexico by their companies, while Mexico joined

121. See Susy Frankel, Test Tubes for Global Intellectual Property Issues (Cambridge University Press 2015) 159-84 (analyzing in detail the national policies on parallel imports of small market economies, namely Israel, New Zealand, and Singapore).

122. 'Jean Monnet: The Unifying Force Behind the Birth of the European Union', available at $<\mathrm{https}$ ://europa.eu/european-union/sites/europaeu/files/docs/body/jean_monnet_en.pdf >.

123. See discussion supra section 2.

124. Ibid.

125. See, eg, Carl Steele, "“Fortress Europe” for Trademark Owners' 1998 Trademark World 14 (Aug. 1998).

126. Critically, on this aspect of the principle of the EEA-wide exhaustion, see Calboli, 'Trademark Exhaustion in the EU', supra (n 10), at 87-90.

127. See Eurostat, 'Intra-EU Trade in Goods: Recent Trends', <http://ec.europa.eu/eurostat/statisticsexplained/index.php/Intra-EU_trade_in_goods_-_recent_trends> (last visited January 20, 2018). 
NAFTA primarily as a source of foreign direct investment from the US and Canada. Interestingly, the position of NAFTA Members over the treatment of exhaustion is converging considerably, with the exception of the position of Mexican law on patents. However, this convergence is not based on the desire to strengthen intra-NAFTA parallel trade and regional market integration. Instead, the current national rules reflect the existing interests of the respective NAFTA Members regarding their position on IP exhaustion and, more generally, international trade. It could even be said that some of the recent changes in this area, for example in the US regarding copyright and patent exhaustion, are simply based on a specific interpretation by national courts of the existing legislative provisions, or lack thereof, or ambiguity therein. In short, these positions do not seem to have anything to do with trade policies related to NAFTA. Moreover, there is nothing to prevent a change in national policies in copyright and/or trademark exhaustion of any NAFTA Member towards national exhaustion. In turn, this would effectively operate as a barrier to legitimate trade and free movement of copyrighted and trademarked goods among NAFTA Members. NAFTA Members also do not follow a principle equivalent to the EU principle of mutual recognition, even though national courts seem inclined to allow parallel imports, as long as the goods are labelled so as to avoid consumer confusion. Thus, material difference in product quality may operate as an additional barrier to trade. ${ }^{128}$

Somewhat in between the EU/EEA and NAFTA is ASEAN. As indicated in section 5, ASEAN Members aim at integrating their national markets, or at least this was the original intention behind the creation of the regional organization. The ASEAN Blueprint specifically states that the free movement of goods is one of the principal means by which the aims of a single market and production base can be achieved. ${ }^{129}$ In this context, the enforcement of IP rights also may represent an undesirable national trade barrier to the free movement of goods, permitting the segmentation of the ASEAN market and increasing the transaction costs of cross-border trade. However, the ASEAN Trade in Goods Agreement (ATIGA) expressly recognizes the protection and enforcement of IP rights as one of the general exceptions to the prohibition of non-tariff restrictions within ASEAN, and the principle of the free movement of goods in the region. ${ }^{130}$ Moreover, while ASEAN has endeavored to promote IP cooperation and understanding among ASEAN Members, it has adopted 'a more flexible IP cooperation model' which 'enables its members to move forward collectively, but at varying paces in accordance with their developmental level and capacity'. ${ }^{131}$ Interestingly, the review of the IP cooperation process from the ASEAN IP Framework Agreement to the IPR Action Plans and Strategic Goals and Measures outlined in the AEC Blueprints from the early 1990s until today reflect a gradually more modest approach towards regional integration as compared to the more ambitious early plans for regional cooperation. Along the same lines, ASEAN never created (nor seemed to desire) regional institutions. ${ }^{132}$ Yet, as the example of the EU demonstrated, institutions are crucial for the long-term creation of a stable and full-scale integrated internal market.

128. See supra section 4.

129. ASEAN, Declaration on the ASEAN Economic Community Blueprint, supra (n 75).

130. ATIGA, supra (n 77), art 8(d).

131. Elizabeth Siew-Kuan Ng, 'ASEAN IP Harmonization: Striking the Delicate Balance' (2013) 25 Pace Int'l L. Rev. 129.

132. Laurence Henry, 'The ASEAN Way and Community Integration: Two Different Models of Regionalism' (2006) 13(6) Euro. L. J. 857-79. 
Still, one of the surprising results of the above analysis is that a considerable number of developing countries in ASEAN follow a system of national exhaustion in trademark and copyright law, in particular in copyright law. ${ }^{133}$ This is surprising because none of these countries has national industries that intensively rely on IP protection, and these provisions favor foreign rather than local economic interests. In particular, national exhaustion allows IP owners - primarily foreign entities with national registrations in these ASEAN Members - to block parallel imports into these countries. In turn, residents of these countries cannot enjoy the economic benefits of parallel imported products through additional product choices and (likely) lower prices. Instead, it would be beneficial for all ASEAN countries to adopt a system of international exhaustion, consistently for all IP rights. This would allow parallel imports of IP protected products from within and outside ASEAN to all ASEAN Members. By adopting international exhaustion, consumers in less developed countries in ASEAN could access more options of goods and availability of the substitutable goods (likely) at a lower price. This approach would also be compatible with the ASEAN Way, as each country would continue to trade on an equal basis with ASEAN and non-ASEAN countries, based on their national interests. As recent economic data indicate that ASEAN Members trade, in large part, with non-ASEAN partners, ${ }^{134}$ this solution would both facilitate intra-ASEAN trade while respecting the current agreements of individual ASEAN Members with other countries.

Certainly, trademark owners and copyright owners would argue that a system of national exhaustion could provide the incentive for them to invest and introduce new products into these countries, based on the assumption that, if no protection is given for higher priced domestic sales, then the following consequences could apply: (1) the new products may never be introduced into those countries; and (2) consumers would thus never benefit from these new products. Yet, in the view of this author, this argument does not easily apply to the specific developing countries at issue in ASEAN, as consumers in these countries could rarely afford higher priced goods, and trademark and copyright owners could even choose not to directly market their products in those countries altogether. In any event, it is the view of this author that, even if trademark and copyright owners were to decide not to market their products in these countries, the benefits of lower prices possibly due to a system of international exhaustion would be higher for the economies of these countries, in terms of consumer access to these products through parallel imports, when compared to the benefits that a system of national exhaustion could entail if trademark and copyright owners were to market their products in the countries directly. Of course, this argument could change if trademark and copyright owners also produced the products in those countries, as such production could benefit national economies. However, no additional benefits may be derived from a system of national exhaustion that would simply permit trademark and copyright owners to control the imports of their products and price discrimination within ASEAN countries.

\section{CONCLUSION}

The comparative analysis of the EU/EEA, NAFTA, and ASEAN, demonstrates how the absence of uniform rules on either international or regional exhaustion may result in jeopardizing the conditions for creating a system of effective free movement of

133. See discussion supra section 5.

134. ASEAN Statistics, Selected basic ASEAN indicators, as of August 2015, <https://www. asean.org/storage/2015/09/selected_key_indicators/table1_as_of_Aug_2015.pdf>. 
products across the territory of the members of a regional organization. Notably, when some of the members of an organization adopt domestic rules in favor of national exhaustion, this disparity of national regimes necessarily results in blocking the cross-border free movement of goods. The same applies when the members of a regional organization practice a non-uniform regime of international and regional exhaustion. In addition, adopting the same rules on exhaustion may not be sufficient to guarantee the effective free movement of goods, when national laws still permit IP owners to successfully block parallel imports when the products are genuine, yet of materially different quality. Unless members of a regional organization also practice a principle of mutual recognition of the product standards - so that products lawfully marketed in one member can be lawfully imported in the other members - an effective and full-scale free movement of goods across the regional organization can be jeopardized by these differences.

To what extent members of regional organizations desire, and accept, the harmonization of national rules on IP exhaustion and agree to embrace a system of mutual recognition depends on several factors, including: the degree of integration that the members of different regional organizations effectively desire to, and realistically can, achieve; the size of their markets, and the respective level of development of the countries; their historical approaches in this area; and so forth. As the development of the EU has demonstrated, the process of market integration in regional organizations is a lengthy process, and national policies related to this integration can shift over time. This is unlikely to happen, however, in regional organizations like NAFTA, whose objective was never to achieve full-scale economic integration. In regional organizations like ASEAN, which aim at creating an internal market, yet adopt a principle of non-interference and lack strong institutions, the transition towards a more robust economic regional integration likely depends on the overall growth of trade within the region and the political will and national interests of its members to pursue such economic integration. 